\title{
The Comparison of Curriculum in Elementary Education between Indonesia and Singapore
}

\author{
Moch. Yusuf Efendi ${ }^{1 *}$, His Nancy Lien ${ }^{1}$ \\ ${ }^{1}$ Department of Education and Human Potentials Development (DEHPD), National Dong Hwa University, \\ Taiwan \\ *yusufefendi662@yahoo.com
}

Received: July $07^{\text {th }}, 2019$

Revised: November $25^{\text {th }}, 2019$

Accepted: January $13^{\text {th }}, 2020$

\begin{abstract}
Indonesia and Singapore, despite having very different approaches to basic education, both perform highly in standardized testing and are respected internationally for their education systems. However, there are many obstacles that should be solved and evaluated so as to provide a solid foundation for students to pursue higher education. Based on this reality, a curriculum comparison needs to be done with countries that already have the best quality education system in this regard Singapore. The objective of the paper is to obtain a summary of the comparison of the curriculum development between Indonesia and Singapore. Indonesia has made several changes in its educational curriculum. The method used is to use a comparative method with a literature review. Indonesia always in low position in international assessment although many things are done to improve the rank of Indonesia. PISA 2015 results positioned Indonesian students in the lowest order. On the contrary, many countries in Southeast Asia are in the top position, such as Singapore which has the best position in Southeast Asia and even on the world level, Singapore is in the top position compared to Indonesia lower than PISA 2015 result shows that the dominance of countries in East Asia. From this study, there are several findings can be adopted in the curriculum of primary schools in Indonesia such as: 1) The application of a uniform curriculum in each school, 2) The function of teachers in preparing their students graduation and 3) The use of instructional media and emphasis on mastery of learning materials. The advantages of this study are: 1) The school can apply the curriculum from the government without ignoring local wisdom, 2) The teachers are able to prepare the students ' preparation earlier, and 3) The teachers can prepare them self to be skill full in operating Information Communication and Technology (ICT) devices.
\end{abstract}

Keywords: Curriculum development; education; elementary school; Indonesia; PISA; Singapore. 


\section{INTRODUCTION}

The curriculum has a function as a reference or basis in carrying out learning activities. It is the first thing that must be prepared well earlier before it's conducted in learning teaching process at school. In addition, the curriculum also serves as a standardization of education.

This paper will discuss curriculum development between Indonesia and Singapore. Discussion focuses on the developments that occur in the curriculum of elementary education and what factors influence these developments.

Indonesia's PISA 2019 results indicate need to use educational provide more efficiently. Biesta (2009) emphasis of the result of Indonesia in the OECD Program for International Student Assessment, or PISA 2015, has become is one of the famous educational events over the past decade for evaluating the quality, equality and efficiently of school systems in providing young people with creative people with creativity skills.

PISA allows governments and educators to identify effective policies that they can adapt to their local context. Biesta (2009) indicated that PISA assesses the extent to with 15-years-old students have acquired key knowledge and skill that are essential for full participation in modern societies. The result of PISA showed that the dominance of countries in Asia (Hong Kong, South Korea, Taiwan, Japan) and Singapore (64 of 65 countries) (OECD, PISA 2016a).
The results of PISA have shown the dominance of countries in Asia (Singapore, Hong Kong, South Korea, Taiwan, and Japan). Indeed, The China Post (2016) released global PISA 2015. The reading had rankings as follows:

....The Program for International Student Assessment (PISA) is an international assessment that measures 15-year-old students' reading, mathematics, and science literacy every three years. First conducted in 2000 , the major domain of study rotates between reading, mathematics, and science in each cycle. PISA also includes measures of general or cross-curricular competencies, such as collaborative problem-solving. By design, PISA emphasizes functional skills that students have acquired as they are near the end of compulsory schooling. PISA is coordinated by the Organization for Economic Cooperation and Development (OECD), an intergovernmental organization of industrialized countries, and is conducted in the United States by NCES. Data collection for the most recent assessment was completed in PISA 2015 assessed students' science, reading, and mathematics literacy in more than 70 countries and education systems. Science was the foal subject of the 2015 data collection, as it was in 2006....

Based on the above explanation, some problems can be raised by providing the following problem statement:

1. What are the factors which influence the curriculum development of the elementary school in Indonesia?

2. What are the factors which influence the curriculum development of the elementary school in Singapore?

3. What is the difference of elementary curriculum development between in Indonesia and Singapore? 
The writing of this paper is limited only to discuss the comparison of curriculum development of education between the countries of Indonesia and Singapore where as a comparison material only doing literature review.

\section{METHODOLOGY}

This paper makes reference to the fundamental interrelation between subject and method. The literature can be obtained from various university libraries, website or other sources which support the idea. Then, the literatures are classified and analyzed into each variable. This research helps us to choose which literature is best used for comparison of the literature (Sudardi, 2003). Classification is an effort to classify information obtained from the relevant literature and website in this case reduce existing data by arranging and classifying the data obtained into a particular pattern or a particular problem to facilitate the reading and discussion as needed. Analysis is the process of simplifying the word into a form that is easier to read and also easy to interpret by linking existing data sources and analyzed in accordance with the items studied in the study. Making conclusions as the final stages of data processing that is the conclusion of the data obtained after the analysis to obtain answers to the reader of what is presented on the background of the problem.

\section{FINDINGS}

\section{a. Curriculum in Indonesia}

Curriculum changes in Indonesia are influenced by changing human needs and outside influences whereby the whole curriculum does not stand alone but is influenced by economics, politics, social culture, science, and technology.

The curriculum of elementary education has changed by policy maker government Indonesia several times from 1947 to 2013. The curriculum changes are influenced by the political, economic, socio-cultural, and scientific and technological developments.

The first curriculum was born in the independence period using the term in Dutch "Leer Plan" meaning lesson plan. The Orientation of Lesson Plans 1947 does not emphasize the education of the mind, but is preferred to character education, state and community awareness. The subject matter is related to daily events, attention to the arts and physical education.

In 1952 the curriculum was refined. This curriculum specifies each subject and is named 1952 Decomposed Lesson Plans. This curriculum has already led to a national education system. The most prominent and characteristic of the 1952 curriculum is that every lesson plan should take into account the content of the lessons that are linked to everyday life.

The principal points of the 1964 curriculum are that the government has a desire for the people to gain academic knowledge for elementary education, so that learning is centered on the 
Pancawardhana Program (Hamalik, 2004), namely moral development, intelligence, emotional / artistic, skillful, and physical. Subjects are classified into five groups of subjects: moral, intelligence, emotional / artistic, skills, and physical. Basic education emphasizes more on practical knowledge and functional activities.

The 1968 curriculum is a renewal of the 1964 curriculum. The structure of the Pancawardhana education curriculum becomes the guidance of Pancasila (the basis of the Republic of Indonesia) those are basic knowledge and special skills. The 1968 curriculum emphasizes the organizational approach of the subject matter: Pancasila soul counseling group, basic knowledge, and special skills.

The 1975 curriculum emphasizes the purpose of making education more efficient and effective. This period is known as the "unit of learning" which is the lesson plan of each unit of discussion. Each unit of instruction is detailed in the form of General Instructional Objectives (TIU), Special Instructional Goals (TIK), lesson materials, lesson tools, teaching and learning activities, and evaluation. The teacher must be skilled at writing down the details of what each learning activity will accomplish.

The 1984 curriculum carries the skill approach process. Although the priority of a process approach, but the goal remains an important factor. This curriculum is also often called an enhanced 1975 Curriculum. Students' position placed as studying subject. The learning process starts from observing things, grouping, discussing, to reporting. This model is called Student Active Learning (CBSA).

The 1994 curriculum was created as a refinement of the 1984 curriculum. The purpose of teaching emphasizes the understanding of concepts and skills in doing exercise and problem-solving. The 1994 curriculum was transformed into a super-solid curriculum. The Presence of Supplements the 1999 Curriculum is more on patching up some material.

The 2004 curriculum, also called Competency Based Curriculum (KBK). A competency-based education program should contain three key elements: the selection of appropriate competencies; specification of evaluation indicators to determine the success of competency achievement; and learning development.

Early 2006 KBK trial was stopped, replaced with Education Unit Level Curriculum (KTSP). Objectives of KTSP include the objectives of national education as well as conformity with the uniqueness, condition and potential of the region, educational units and learners. The formulation of KTSP is the responsibility of the school under the supervision and monitoring of the local education and local government offices. By the end of 2012 KTSP is considered to be less successful, because the schools and teachers have not fully understood KTSP and the emergence of diverse curricula that are difficult to achieve national education goals. So, starting early 2013 KTSP was stopped at several 
schools and replaced with a new curriculum.

The 2013 curriculum is a refinement, modification and updating of the previous curriculum. The 2013 curriculum has been implemented in the 2013/2014 school year at certain schools (limited). The 2013 curriculum was officially launched on 15 July 2013. The idea of integrated thematic learning embedded in the Curriculum 2013 policy, especially for elementary school level cannot be separated from the political process of education that surrounds it. The success of educational politics as well as the 2013 Curriculum Policy will also use domains as known in political science such as power, influence, conflict, and authoritative allocation of values (Wong, 1995: 21).

The Integrated Thematic Learning Policy becomes an important aspect of the delivery system of the Curriculum 2013 itself. Since the 2006 School Curriculum has been introduced with integrated learning approaches such as for Natural Science (IPA) and Social Sciences (IPS) in Junior High School / Madrasah Tsanawiyah (MTs). At the primary school level there is encouragement and endeavor for teachers to use integrated thematic learning especially for low classes from grade 1 to grade 3 . Learning experiences in the previous curriculum, which tend to be disciplined, loaded with cognitive material loads, over lapping between the same materials in different subjects is one of the reasons for the need for integrated thematic learning applied since elementary school.

By the 2013 Curriculum Developers it is believed that integrated thematic learning is one of the most effective teaching models (highly effective teaching model). In addition, integrated thematic learning is considered capable of accommodating and touching in an integrated dimension of emotion, physical, and academic (Ministry of Education and Culture, 2013). Minister of Education and Culture Regulation no. 67 of 2013 affirms that the 2013 curriculum for elementary schools is designed using integrated thematic learning. The design is applied from grade 1 to grade 6 .

The globalization era will change the lifestyle of society from agrarian and traditional commerce to modern industrial and commercial society as seen in WTO, ASEAN Community, APEC, and AFTA. Future challenges are also linked to the shift of world economic power, the influence and impact of techno-sciences and the quality, investment, and transformation of education.

Wiles Bondi (in Sudrajat, 2008) in his book 'Curriculum Development: A Guide to Practice' also explains the political influence in the formation and development of the curriculum. It is clear that curriculum development is influenced by the political process, because of every time a country's executive chair exchanges, then every time that education curriculum changes.

The social-cultural reality contained within a community is the study material for curriculum development used as the 
foundation for curriculum development. Israel Scheffer (in Sukmadinata, 2006: 60) argues that through education, humans recognize the past civilization, participate in civilization now and make the civilization of the future. Thus, the developed curriculum should be considered, responding and based on socio-cultural developments within a society, both locally, nationally and globally.

Science and technology are values that come from mind or logic, whereas art comes from feelings or aesthetics. The main characteristic of society is always growing. This development can happen quickly or slow even very fast. Science and technology strongly support the development of society.

Indonesia has made various changes and improvements in curriculum policies. The curriculum can be categorized as a dynamic, contextual, and relative policy product. Dynamic because it continues to grow and adjust with the times and open to criticism. Contextual as it is needed and based on the context of its time. And relative because the outcome of the curriculum policy is considered good or perfect in its day and will become irrelevant in later ages. Therefore, the basic principle in curriculum policy is change and continuity that is the change which is done continuously

Learning in the 2013 curriculum emphasizes the modern pedagogic dimension of using a scientific approach. The thematic learning process using a scientific approach according to Kemendikbud (2013) is intended to provide understanding to students in knowing, understanding various materials using a scientific approach, that information can come from anywhere, anytime, not dependent on the teacher's online information. This is because the learning process must touch the three domains of attitude, knowledge, and skills.

According to Depdiknas (in Trianto, 2010: 79) thematic learning as a model of learning including one type/type of integrated learning model. The term thematic learning is basically an integrated learning model that uses themes to link some subjects so that it can provide meaningful experiences to students. Sutirjo \& Mamik (in Suryosubroto, 2009: 133) suggests that thematic learning is an attempt to integrate knowledge, skills, values or learning attitudes and creative thinking using themes. Meanwhile, according to Rusman (2012: 254), thematic learning is one integrated learning model (integrated instruction) which is a learning system that allows students both individually and actively groups to explore and find the concept and principles of science holistically, meaningful and authentic.

Thematic lesson places more emphasis on student involvement in the learning process and directs students actively involved in the learning process. In the implementation of thematic learning has several advantages and disadvantages.

According to Suryosubroto (2009: 136-137), there are several advantages 
and disadvantages of thematic learning are:

\section{The advantages of thematic learning}

a. Fun because it departs from the interests and needs of students.

b. Experience and learning activities relevant to the level of development and needs of students.

c. Learning outcomes will last longer because they are memorable and meaningful.

d. Growing social skills such as working together, tolerating, communicating and responding to the ideas of others.

\section{Lack of thematic learning}

a. Teachers are required to have high skills.

b. Not every teacher is able to integrate the curriculum with the concepts that exist in the subjects appropriately.

\section{b. Elementary Curriculum in Indonesia}

Singapore's changes to the curriculum landscape must be understood in their historical context (colonial period: 18191959; post-colonial period: 1959-1987). The colonial inheritance was a school system differentiated along medium of instruction lines (English, Chinese, Malay, and Tamil), and within each section, the curriculum, curriculum materials, and assessment were different. The postcolonial effort was directed toward creating a national curriculum and achieving standardization (Gopinathan, 1974; Lim \& Gopinathan, 1990). By the 1980s, Singapore had a national curriculum in place, supervised by the Curriculum Development Institute of Singapore (CDIS), a MoE agency. A highstakes examination system was also in place.

Education in Singapore began under British rule in 1823 by Sir Thomas Stamford Raffles who founded the Singapore Institute (now known as the Raffles Institute) in 1823. Then, there are three types of schools emerging in Singapore namely Malay schools, Chinese and Tamil schools, and English school. The Malay School is provided free of charge for all students with English as the main language in the teaching and learning process. Most Tionghoa and Tamil schools use their own mother tongue.

In 1947, a ten-year education program was formulated. Between the 1950s and 1960s, when Singapore's economy began to develop, Singapore adopted an educational system that provides skilled labor as an industrialization program aimed at reducing unemployment. The bilingualism policy at school was officially introduced in 1960, beginning with establishing English as the official language of the country. Education for children of all races and backgrounds began to take shape.

In the 1980s, Singapore's economy began to prosper. This makes the Singapore education system change from quantity to quality. Differentiation for students with different academic skills began to be implemented, such as 
improvements to the vocational education system and the establishment of a new Technology Institute.

In 1997, the education system in Singapore began to turn into "AbilityBased" after Prime Minister Goh Chok Tong formulated an educational vision as a place to study the nation (Gopinathan, \& Mardiana, 2013). This policy emphasizes national education, creative thinking, collaborative learning, and ICT learning. Schools are becoming more diverse and given more free autonomy in determining their own curriculum and academic potential in the region. The differences between the various academic schools are starting to disappear. The Ministry of Education officially states that "perfection" is not only measured in academic terms, just as the "perfection" mountains have many peaks (Gopinathan \& Mardiana, 2013).

In accordance with the 21st century competency curriculum proclaimed by the Ministry of Education, Singapore (2011) stated that the curriculum for elementary schools classified into three groups of abilities that are Fundamental consists of Mathematics \& Science, Languages and Humanities \& Arts, Knowledge Skills and Life Skills

Industrialization in the late 1960s demanded that Singapore produce sufficient skilled workers for an exportoriented economy. Responding to this demand, there was a shift in emphasis from academic to technical education, characterized by the development of post-secondary technical and vocational education at the polytechnics (Gopinathan \& Ho, 1999).

All children start primary school education at age 7. This is a compulsory six-year course designed to give them a strong educational foundation. It aims to develop language and numeracy skills, build character and nurture sound values and good habits. At the end of Primary 6, students take the Primary School Leaving Examination (PSLE), which assesses their suitability for secondary education and places them in a secondary school course that matches their learning pace, ability, and inclinations. Students can also seek admission to a secondary school based on their diverse strengths and interests in areas such as art and sports through the Direct School Admission exercise (MOE, 2016a). At the lower secondary levels (grades 7 and 8), students experience a broad-based education in the languages, the humanities and the arts, mathematics, and sciences, design and technology, physical education as well as character and citizenship education. At grades 9 and 10, all students learn two languages, social studies, and mathematics, and select from a wide range of elective subjects and programmed (MOE, 2016b).

\section{DISCUSSION}

\section{a. Implication of Elementary Curriculum in Indonesia}

The governments or policy makers curriculum and educators will struggle to compete internationally in knowledge creation, thus making it more difficult for Indonesia to transition to a knowledge- 
based to improve scientists and researcher knowledge and research are available to inform policy decisions (Suharti, 2013).

What does the teacher had need educational reform and curriculum to enhance learning and teaching system adopt the gain of technology innovation educational reform in Indonesia? Nowadays, the teacher had need educational reform and curriculum to enhance learning and teaching system adopt the gain of technology innovation educational reform. Suharti (2013) argued that the requirement for being teacher is more complex, they need to improved ability, such as knowledge about the student, known to adopt and operate a new technology in learning to conducted critical thinking and problemsolving.

"When teachers frequently explain and demonstrate reading's score ideas, and discuss students' questions, students score higher in science and have stronger beliefs in the value of scientific inquiry and are more likely to expect to work in a reading-related occupation later on." In the case of Indonesia, the resources are there. Education dominates social spending and $20 \%$ of the budget has to go to education (CMEC, 2016).

The PISA Report 2015 has found that Indonesia's quality of schools' educational resources is one of the highest (fourth out of 69) among PISAparticipating countries and economies. Having said that, this does not mean that schools in Indonesia have all that they need. Some regions are still poorly equipped (CMEC, 2016).

Primary and secondary education is the foundation of the Indonesian knowledge sector should to improved regarding reading for Indonesian can analyze and interpret models of reading's score compared to other countries participating in PISA. Primary and secondary schools have to equip students with the analytical required to become reading. They also have to inspire students to want to become researchers in any field. (Muhaimin \& Ali, 2001).

The PISA 2015 results show that Indonesia is still struggling. Without skilled students leaving compulsory education, Indonesian universities will not be able to expand and their research programs and improve their international standing. The report points out the same education problem again i.e. content and rote learning orientation, that is being promoted by the Indonesian national exam structure as well as a lack of connecting the textbook knowledge to reality by discussion, experimentation, etc. (Berry, R., 2011).

The foundations that teachers need to get attention by in the thematic learning include philosophical foundations, psychological foundations, and practical foundations.

\section{Philosophical Foundation}

Philosophically, the emergence of thematic learning is influenced by three schools of philosophy as follows: 
1. Progressivism, more emphasis on the formation of creativity, giving a number of activities, a natural atmosphere (natural), and attention to student experiences.

2. Constructivism, Knowledge cannot be transferred away from a teacher to a student but must be interpreted by the students themselves.

3. Humanism sees students in terms of uniqueness, potential, motivation it has. Lesson services in addition to being classical, also individual.

\section{Psychological Foundation}

Students are individuals who are in the process of development, such as physical/physical, intellectual, social, emotional, and moral development. The main task of the teacher is to optimize the student's progress.

\section{Practical foundation}

A practical foundation is necessary because teachers must basically implement thematic appraisal in the classroom.

\section{b. Implication of Elementary Curriculum in Singapore}

The 21 Century framework guided the development of subject syllabi and instructional materials. Schools also use the framework to design curricular and co-curricular programmers that will help students develop the requisite competencies. Each school in Singapore offers a range of learning experiences to develop students holistically.
Through co-curricular programmers and outdoor education, students can develop their interest and talent in music, arts, and sports, and hone their leadership skills and social and emotional competencies. In addition, every student participates in Values-in-Action programmers that help to build a sense of social responsibility towards their community (MOE, 2016a).

Teachers are the pillars of Singapore's education system and the Ministry encourages them to be at their professional best. After initial pre-service training at the National Institute of Education (NIE), teachers are expected to continue to build their capabilities as teaching professionals through various in-service opportunities.

The culture of dedication, collaborative learning, and professional excellence is expected to be further strengthened by teacher academies, language institutes, and professional learning communities.

\section{CONCLUSSION}

In general, the finding of the present study shows four points, there is the development of education in some Southeast Countries:

1. Education has been developed, Indonesia is due to make a change for eight times from independent day until now. Since Indonesia is very spacious and consists of several islands and ever-changing education policyholder following the change of government. So that education cannot be developed rapidly as the country's neighbors. 
2. Educational reform in Singapore has grown as a model to support the advancement of education in Singapore and also of success that can affect of economics, development, political and social, so as to bring together from several tribes and races covered in Singapore. Education in Singapore too prioritizes the results and processes, but ignore the aspect of the character and a lack of attention, so that the public hedonism and capitalism.

3. Curriculum can be classified into some category as follows:

a. Curriculum aspects that consists of competence, learners, implementers and evaluation.

b. Curriculum Purpose is the purpose that is prepared and developed to achieve the educational goals so that learners can be productive, creative, innovative, and effective and able to contribute to the life of society, nation, state, and world civilization.

c. Curriculum compilers are the parties concerned and have authority in the preparation and development of the curriculum.

d. Curriculum content is identical with the assignment of subject names or subject titles.

e. Assessment system is as a process of collecting and processing information to measure the achievement of learning outcomes Learners (Permendikbud No. 66 of 2013) f. Learning process is a process in which there is interaction activity between teacher-student and reciprocal communication that takes place in educational situation to achieve learning objectives (Rustaman, 2001: 461).

The curriculum in Indonesia, especially the primary school curriculum will provide benefits for basic education. Therefore, as a learning material for elementary school students in Indonesia, it is necessary, the curriculum that is considered not contradictory and not difficult for teachers and students in the implementation of the curriculum but will provide good quality for the success of students in education to a higher level. As a suggestion implication, the authors suggest to adopt the Singapore curriculum as follows:

1. Curriculum in elementary school has same local content and applied in each region.

2. Teachers are subject to follow the established curriculum, give more emphasized-on mastery the course and practice and also focus on preparing students for graduation exams for higher education.

3. The use of textbooks, student worksheets, student teaching media, and exercises should be used to the maximum extent possible.

\section{REFERENCES}

Berry, R. (2011). Assessment reforms around the world. In R. Berry \& B. Adamson (Eds.), Assessment reform in education, policy and 
practice (pp. 89-102). Dordrecht: Springer.

Biesta, G. (2009). Good education in an age of measurement: On the need to reconnect with the question of purpose in education. Educational Assessment, Evaluation and Accountability, (21)1, 33-46.

CDT, China Digital Time. (2015). Do Shanghai's PISA scores reflect Chinese education? Retrieved from http://chinadigitaltimes.net/2013/12 /shanghais-pisa-scores-reflectchinese-education/. Accessed at April 27, 2017.

Chen, P. (2000). Ability-driven education in post-secondary institutions. Address by Mr Peter Chen, Senior Minister of State for Education at the first symposium on teaching and learning in higher education on Thursday $6^{\text {th }}$ July 2000 at 9:00 am at the Engineering Auditorium, Faculty of Engineering, National University of Singapore.[Online] http://www.moe.gov.sg/speeches/2 000/sp06072000_print.htm [2005, February 7].

Chen, P. S. (2010). jiǔ nián yī guàn kè chéng zhèng cè zhí háng píng xī [Comment and analysis of the policy implementation of grades 1-9 program]. jiāo yù zì liào yǔ yán jïū shuāng yuè kān [Bimonthly Journal of Educational Resources and Research] 92, 47-74.

CMEC. (2015). PISA 2015. Canada: The council of Ministers of Education. Retrieved from: http://cmec.ca/508/Programs-and
Initiatives/Assessment/Programmefor-International-StudentAssessment-(PISA)/PISA2015/index.html. Accessed at April 24, 2017.

Di Grapello, E. (2013). Role of education and training sector in addressing skill mismatch in Indonesia. In D. Suryadharmal \& G.W. Jones (Eds.). Education in Indonesia (pp. 236 266). Singapore: Institute of Southeast Asian Studie.

Driskell, N. (2014). Global perspectives:

Explaining Taiwan's dramatic improvement in PISA reading. Washington, DC: NCEE (National Center on Education and The Economy). Retrieved from http://www.ncee.org/2014/10/glob al-perspectives-explaining-taiwansdramatic-improvement-in-pisareading/.

Gopinathan, S., \& Mardiana, A. B. (2013). Globalization in Singapore curriculum. In Deng, Z., Ghopinatan, S., \& Lee, C. K. (Eds.), Globalization in Singapore curriculum (pp.15-32). Singapore: Springer.

Gopinathan, S., \& Ho, W., K. (2001). Challenges Facing the Singapore Education System Today. Edited by Jason.

Gopinathan, S., (1974). Towards A National System of Education in Singapore 1945- 1973. Singapore: Oxford University Press.

Hamalik, O. (2011). Kurikulum dan Pembelajaran. Jakarta: PT. Bumi Aksara. 
Huang, Y., Y. (2001). Probing activity curriculum and integrated activity curriculum from system-theory viewpoints: Essence, rationale and prospect. Research in Applied Psychology, 9, 215-251.

Joni, T., R. (1983). Cara Belajar Siswa Aktif, Wawasan Kependidikan, dan Pembaharuan Pendidikan Guru. Departemen Pendidikan dan Kebudayaan. IKIP Malang.

Kementerian Pendidikan dan Kebudayaan, (2013). Materi Sosialisasi Kurikulum 2013 untuk Asesor Sertifikasi Guru, di Rayon 111 Universitas Negeri Yogyakarta, Juli 2013.

Kementerian Pendidikan dan Kebudayaan (2013). Buku Tematik Terpaduk Kurikulum 2013. Buku Siswa dan Buku Guru Kelas 1 dan Kelas 4. Tersedia di bse.kemdiknas.go.id

$\mathrm{Li}$, L. Quiet revolution in the classroom: The nine-year integrated curriculum. (R. Taylor, Trans.). SINORAMA Magazine. Retrieved March 05, 2019, from http://www.sinorama.com.tw/en/print issue.php3?id=200229102016e.txt\& mag=past

Lin, Y., Wei. (1998). The preparation of early chilhood teacher in Taiwan. Journal of Nasional Taiwan Normal University in Education, 43(2), 53-56.

Lim, S. T., \& Gopinathan, S. (1990). Twenty-five years of curriculum planning. In J. Y. S. Kwong \& W. K. Sim (Eds.), Evolution of educational excellence: 25 years of education in the Republic of Singapore (pp. 5980). Singapore: Longman.

Materi pemaparan Menteri Pendidikan dan Kebudayaan RI dalam Sosialisasi Kurikulum 2013 bagi Pengurus PGRI, Kepala Sekola, dan Guru YPLP PGRI Jawa Tengah di Semarang pada tanggal 23 Februari 2013.

Muhaimin, S. A., \& Ali, N. (2001). Paradigma Pendidikan Islam: Upaya Mengefektifkan Pendidikan Agama Islam di Sekolah. Bandung: Rosda Karya.

OECD (Organisation for Economic Cooperation and Development). (2012). Lesson from PISA for Japan, strong performers and successful reformers in education. Paris: OECD Publishing. Accessed at April 16, 2017.

OECD (Organisation for Economic Cooperation and Development). (2015a). PISA 2015 assessment and analytical framework: Mathematics, reading, science, problem-solving and financial literacy. Paris: OECD Publishing. Accessed at April 17, 2017.

OECD (Organisation for Economic Cooperation and Development). (2015b). PISA 2015: Draft science framework. Paris: OECD Publishing. Accessed at April 17, 2017.

OECD (Organisation for Economic Cooperation and Development). (2016a). PISA 2015 results: What students know and can do student performance in mathematics, reading and science 
(Volume I, Revised edition, February 2016). Paris: OECD

Publishing. Accessed at April 16, 2017.

OECD (Organisation for Economic Cooperation and Development). (2016b). PISA 2015 results in focus: What 15-year-olds know and what they can do with what they know. Paris: OECD Publishing. Retrieved from www.oecd.org/pisa. Accessed at April 17, 2017.

Peraturan Menteri Nomor 67 Kerangka Dasar dan Struktur Kurikulum SD/MI. (2013). Jakarta: Departemen Pendidikan dan Kebudayaan RI.

Peraturan Menteri Nomor 68 Kerangka Dasar dan Struktur Kurikulum SMP/MTs. (2013). Jakarta: Departemen Pendidikan dan Kebudayaan RI.

PIRLS.,(2015).

Timssandpirls.bc.edu/pirls2015/inter national-results-pirls.htm. Accessed at April 16, 2017.

Rustaman. (2001). Ketrampilan bertanya dalam pembelajaran IP. Dalam hangout bahan pelantikan guruguru IPA SLTP se-Kota Bandung di PPG IPA. Departemen Pendidikan Nasional.

Sudardi, B. (2003). Penggarapan Naskah. Surakarta: Badan Penerbit Sastra. Indonesia.

Sudrajat, A. (2008). Pengembangan Kurikulum (http://istpi. wordpress.com/2008/10/27/penge mbangan-kurikulum/ diakses pada tanggal 20 Nopember 2008).
Suharti. (2013). Trend in education in Indonesia. In D. Suryadharma \& G. W. Jones (Eds.), Education in Indonesia (pp. 15-52). Singapore: ISEAS (Institute of Southeast Asian Studies).

Sukmadinata, N., S. (2006). Pengembangan Kurikum; Teori dan Praktek. Bandung: Remaja Rosdakarya.

Suryosubroto. (2009). Proses Belajar Mengajar di Sekolah. Jakarta: Rineka Cipta. HIm: 132, 1361-137. Suharti (2013). Trend in education in Indonesia. In D. Suryadharma \& G. W. Jones (Eds.), Education in Indonesia (pp. 15-52). Singapore: ISEAS (Institute of Southeast Asian Studies).

Suprapto, N., \& Pai, Yi- fong., (2015). Promoting Science Centers by using MOOCS: Model for communicating informal science education. Man, In India, 95 (4): 1005-1012.

Suprapto, N., (2016). What should educational reform in Indonesia look like? - Learning from the PISA science scores of East-Asian countries and Singapore. The Hong Kong Institute of Education.

Tan, C. (2008). Globalization, the Singapore state and educational reforms: Towards performativity. Education, Knowledge and Economy, 2(2), 111-120.

The act of the Republic of Indonesia Number 20 National Education System. (2003). Jakarta: House of People's Representatives and President. 
The China Post. (2015). Taiwan placed 4th in OECD global education ranking. Retrieved from:http://www.chinapost.com.tw/ taiwan/national/nationalnews/2015/05/14/435999/Taiwanplaced.htm. Accessed at April 17, 2017.

Trianto. (2010). Mendesain Model Pembelajaran Inovatif-Progresif. Jakarta: Kencana.

UNDP. (2015). Human development report 2014: Indonesia. Retrieved from http://hdr.undp.org/sites/all/themes /hdr theme/country-notes/IDN.pdf. Wong, K., J. (1995). The politics of education: From political science to interdisciplinary inquiry. Dalam Jay D. Scribner \& Donald H. Layton (eds.), the Study of Educational Politics. Washington D.C, \& London: The Falmer Press, pp. 21-35. Yudikustiana. Sistym Pendidikan singapura.

http://yudikustiana.wordpress.com/2011/ 05/27/sistem-pendidikan-disingapura/. 